\title{
KRIYA KERAMIK: WUJUD, POSISI, DAN PERANNYA \\ DI MASA KINI
}

\author{
Akbar Adhi Satrio *)
}

\begin{abstract}
This article act as a response for what is kriya especially ceramic craft in nowadays context. Public usually knows about ceramic is limited to traditional terracotta product that they usually found in a craftsmen village or an industrial mass produce ceramic that they always use in their everyday life. Kriya (or craft in the western term) now has grew more not only limited in the scope of tradition or even a mass product only. There are many new small independent studio emerge as a new perception that combine the potential of both industrial and traditional have. The role of educational institutions are producing graduates working in the field of ceramic craft has established a new perception on how it should craft in contemporary ceramics put his position in the midst of globalization. Ultimately concluded that the ceramic craft began to position himself to a wider sphere, not only as a center for craftsmen but also intangible and handicraft industries based independent studio-based designermaker.
\end{abstract}

Keywords : kriya, ceramic, culture, identity

\section{Pendahuluan}

Terminologi perubahan tidak selalu berkonotasi dengan kemajuan yang lebih baik namun tidak sedikit yang menyimpan sisi gelap nilai-nilai yang dibawanya, seperti perpecahan dan krisis identitas. Konteks 'kekinian' mengaburkan pandangan masyarakat, yang kemudian secara sengaja maupun tidak, mengoposisibinerkan dengan 'kemasalampauan' yang identik dengan konten tradisi dan ketinggalan zaman, sehingga gejala sosiokultural tersebut mengantarkan spirit budaya tradisi masa lampau yang dulu tumbuh dan berkembang kepada sebuah eksistensi dilematis (Kasiyan, 2009: 405-406). Di samping itu kita juga berhadapan pada sebuah "kegalauan" kultural yang membuat arus budaya berhenti pada satu momen dengan kondisi kebaruan yang memiliki banyak batasan dalam bergerak, khususnya dalam pengembangan tradisi yang berkaitan dengan penciptaan artefak.

Kriya sebagai salah satu bagian dari budaya Indonesia, telah memiliki catatan sejarah yang cukup panjang pula dan bahkan mampu berkontribusi bagi konstruksi jati diri dan kearifan lokal ke-Indonesia-an melalui artefak-artefak yang dihasilkan. Walaupun masih dalam perdebatan, terminologi kriya kerap menjadi padanan kata craft di dalam perspektif barat. Seperti yang dipaparkan oleh Gustami (1992: 71), kriya dimaknai sebagai "karya seni yang unik dan karakteristik di dalamnya mengandung muatan nilai estetik, simbolik, filosofis, dan fungsional serta ngrawit dalam pembuatannya".

* Akbar Adhi Satrio (akbaradhisatrio@gmail.com), Mahasiswa Magister Desain - Institut Teknologi Bandung 
Keterampilan tangan menjadi utama di dalam proses berkarya kriya, namun bukan berarti menjadi satu-satunya poin penting. Terdapat keilmuan lain yang diperlukan bagi praktisi kriya dan hasil karyanya untuk bisa dianggap sebagai sebuah karya atau produk kriya. Perlu ada pemahaman intelektual dan kreativitas dalam membangun produk atau karya kriya. Ini sudah harus menjadi perhatian karena saat ini istilah kriya lebih sering disamaratakan dengan barang-barang kerajinan rakyat. Pendapat ini tidak sepenuhnya salah akan tetapi konteksnya sudah tidak tepat lagi karena tidak semua produk kriya adalah produk kerajinan rakyat.

Indikasi-indikasi baru mulai dan sedang bermunculan hingga detik ini yang menandakan bahwa kriya sudah bergerak menuju pemahaman baru dan beragam. Di sektor industri telah muncul pola baru dalam proses desain dan produksi benda yang bersifat massal namun tetap memiliki pertimbangan akan keterampilan tangan manusia yang diangkat sebagai nilai jual sebuah produk, sehingga setiap barang yang diproduksi memiliki ciri khas produk buatan tangan walaupun memiliki desain yang sama. Studiostudio kriya mandiri pun kini mulai bermunculan yang pada umumnya diprakarsai oleh lulusan program studi kriya, desain, dan bahkan seni. Praktik dan proses kreasinya pun tidak selalu berangkat dari tradisi dan adat akan tetapi sudah mulai mempertimbangkan unsur-unsur desain yang sistematis. Oleh karena itu, perlu ada kajian lebih lanjut mengenai posisi kriya saat ini dengan memetakan kembali indikator-indikator penyusunnya berdasarkan pengertian yang telah ada dan berbagai pemahaman akan proses penciptaan kriya yang telah berkembang dikaitkan dengan realita di lapangan baik di sentra perajin, studio, maupun industri. Studi kasus yang dipilih dikerucutkan kepada bidang kriya keramik.

\section{Manusia dan Budaya Materi}

Manusia dalam perkembangannya akan terus mencoba menyesuaikan diri dengan lingkungannya dan di saat yang bersamaan lingkungan itu pun turut bertumbuh dan berkembang dengan segala elemen pendukung dan kebutuhannya. Kondisi ini memaksa manusia untuk dengan cepat memenuhi kebutuhan diri dan lingkungannya dengan berbagai cara yang kadang justru membuatnya terjebak dalam tuntutan lingkungan, namun di sisi lain manusia juga mampu menentukan pilihan solusi berdasarkan tingkat perkembangan dan kondisi jasmani maupun rohaninya. Pada akhirnya apapun respon tindakan yang dilakukan manusia selalu membawa konsekuensi pada diri pribadi dan juga lingkungannya. Ahadiat Joedawinata (2008: 58) berpendapat bahwa desain sebagai objek bukan semata-mata hanya berada di dalam ruang ekspresi estetis, simbolis, dan fungsi praktis tetapi juga mempertimbangkan bagaimana cara mencapainya berdasarkan konsep dan sifat material, teknik, dan sumber energi.

Manusia merupakan makhluk yang terdiri atas unsur raga atau fisik biologis, jiwa atau psikologis, dan sosial kultural. Faktor fisik memberikan kemampuan namun sekaligus memberikan ketentuan pada manusia untuk melakukan kegiatan dan sampai batas apa seseorang dapat melakukan kegiatan. Faktor psikologis serupa dengan faktor fisik namun dalam bentuk kondisi mental dan akal sebagai penentu keputusan. Sedangkan faktor yang terakhir yaitu sosial kultural merupakan faktor lingkungan tempat yang membentuk pola hidup manusia yang seiring dengan waktu membentuk kebiasaan, kebudayaan, tradisi, 
dan norma yang berlaku akibat proses yang berulang kali dilakukan. Ketiga faktor tersebut membentuk kebutuhan, keinginan, dan rasa takut pada diri manusia dalam menyesuaikan dirinya dengan lingkungan tempat dia hidup. Namun dalam prosesnya ketiga hal tersebut pada akhirnya akan ikut membentuk wujud fisik dan kepribadian manusia itu sendiri serta kehidupan sosial dan budayanya. Dalam proses berlangsungnya siklus tersebut, manusia menciptakan banyak hal dalam usahanya mempertahankan hidup dan eksistensinya. Salah satu wujudnya berupa benda atau produk sebagai alat untuk membantu usaha pemenuhan kebutuhan.

Sebuah artefak dalam wujud produk terbentuk oleh faktor fisik yang terdiri atas teknik, material, energi, dan sumber-sumber lain yang mendukungnya. Ketersediaan faktorfaktor ini tidak sama di setiap daerah, ini merupakan salah satu penyebab adanya keragaman budaya materi. Selain faktor fisik, sebuah artefak produk juga memiliki muatan nonfisik berupa fungsi praktis berdasar tujuan produk tersebut diciptakan dan kaitannya dengan aplikasi produk, simbol-simbol atau muatan budaya dan tradisi yang terkandung di dalam produk tersebut.

Indonesia merupakan contoh nyata dari teori tersebut. Dapat kita cermati bahwa faktor utama yang membentuk keragaman budaya di Indonesia salah satunya adalah kondisi geografis yang berbeda-beda. Dari kondisi geografis yang berbeda, potensi alamnya pun akan berbeda. Hal ini pula yang menjadi penyebab di setiap daerah menghasilkan budaya, bahasa, dan artefak atau produk-produk yang berbeda bergantung pada apa yang disediakan alam di sekitarnya. Oleh karena itu, setiap daerah di Indonesia memiliki produk kriya yang khas, contohnya daerah Sumatera Utara dengan kain ulos, Jawa Barat dengan produk-produk berbahan dasar bambu, dan Kasongan yang terkenal dengan produk keramiknya.

\section{Manusia dan Tradisi}

Jika dicermati lebih dalam, tradisi pada dasarnya telah mengajarkan kita prinsip-prinsip desain melalui artefak-artefak yang dihasilkan dan dikembangkan. Artefak tradisi merupakan hasil pembelajaran selama ribuan tahun pengalaman yang mengandung nilai-nilai estetika dan fungsi, tujuan fisik dan ideologis, serta keputusan ekonomi dan ekologi (Nugraha, 2010: 22). Semua faktor tesebut merupakan cerminan dari identitas lokal. Akan tetapi diangkatnya kembali nilai-nilai tradisi ke dalam wujud desain yang baru bukan proses yang instan, baik dalam aplikasi aspek kegunaan praktisnya, estetisnya, maupun faktor kultur sosialnya. Ketiga aspek tersebut kini lebih sering dikembangkan secara terpisah dan tidak menjadi sebuah kesatuan yang saling berkesinambungan, sehingga yang terjadi pada umumnya seolah-olah hanya sekedar membuat replika dari artefak tersebut atau hanya mengambil sebagian unsur-unsur estetisnya untuk diaplikasikan ulang secara mentah dan berakhir sebagai hiasan dengan label identitas daerah tertentu semata. Hal ini disebabkan kurangnya perhatian para pengembang desain terhadap hal-hal yang konseptual dalam pembentukan suatu benda atau artefak yang berperan sebagai unsur pemandu sekaligus pembeda (Joedawinata, 2008: 58). Desainer yang terlibat dalam proses desain perlu meninjau tujuan awal desain dari suatu produk artefak sebagai referensi data dan konsep, sehingga tidak serta-merta menggunakan pembenaran semata sebagai latar belakang desain dan tidak melihat kebutuhan dan keinginan penggunanya serta kemampuan produksi dan material yang tersedia di masa kini. 
Mengkaji artefak pada masa lampau berarti memahami pola komunikasi antara artefak dengan subjek melalui panca-inderanya berdasarkan gagasan dan pengalaman pada masa itu (Sumardjo, 2006). Oleh karenanya, komunikan yang dituju adalah masyarakat pada zaman benda beserta segala sesuatu yang terkandung padanya diciptakan. Saat artefakartefak masa lampau hadir di masa kini, belum tentu masyarakat modern dapat memperlakukannya sesuai dengan tujuan pertama artefak tersebut dibuat. Artefak yang dahulunya dianggap keramat bisa jadi sesuatu yang bernilai profan di masa kini karena tidak adanya toleransi dalam perbedaan cara membaca. Perlu ada pemahaman dalam membaca sebuah teks dengan konteks, yakni dengan memahami cara berpikir masyarakat pencipta artefak. Dengan memiliki pemahaman yang baik akan hal tersebut dalam mendesain, diharapkan desainer mampu menghasilkan desain yang tidak hanya up to date namun secara bersamaan mampu melestarikan kekayaan estetika tradisional di Indonesia.

\section{Kriya dan Posisinya Saat ini}

Fenomena kriya di Indonesia dalam beberapa tahun terakhir memang menjadi perhatian. Adanya wacana postmodern di satu sisi telah membuka peluang bagi ideologi dan budaya berbasis lokalitas, etnis, dan semacamnya untuk bangkit kembali setelah, seperti yang dipaparkan di atas, melalui era bahwa kriya hanya dianggap sebagai produk masyarakat akar rumput. Hal ini dapat menjadi batu loncatan bagi kriya untuk bangkit dan berkembang, baik akademisi maupun praktisi. Pernyataan ini penulis utarakan mengacu pada pendapat Agung Wicaksono (2009: 209) sebagai berikut:

Peluang seni kriya untuk dikembangkan dan dilestarikan sangat besar, baik
SDM pendukung, nilai-nilai yang inheren pada budaya sekelilingnya, teknik pembuatan, lingkungan pendukung, dan apresiator atau penggunannya. Masyarakat dunia sedang mencari kearifan-kearifan lokal yang dapat menjawab pertanyaanpertanyaan atau masalah-masalah yang dihadapi pada saat ini.

Hal ini kemudian diyakini sebagai prospek bisnis yang cukup menguntungkan dari segi ekonomi. Industri yang berbasis kriya satu per satu kini telah terlihat muncul dan meramaikan kembali produk-produk berbasis budaya bangsa. Dari sudut pandang ekonomi, fenomena ini dapat disikapi sebagai respon yang positif, mengingat keragaman usaha membuka peluang baru bagi investasi di bidang kriya yang dianggap mampu memberikan jawaban kepada masyarakat, tidak hanya di Indonesia namun juga masyarakat global, akan pencarian identitas masa lalu dengan kemasan masa kini. Kehausan akan jawaban tersebut dijawab dengan terburu-buru dan mendorong munculnya euphoria dan pada saat yang sama, menciptakan budaya kepanikan. Budaya tidak lagi diterjemahkan melalui perenungan nilainilai atau simbol filosofis tapi dihadirkan kepada masyarakat sebagai testimonial masa lalu dan kemudian menjadi acuan desain bagi produk-produk mereka, sehingga yang terjadi sekarang adalah secara estetika bentuk dan desain produk-produk kriya masa kini memenuhi syarat sebagai representasi kebudayaan masa lalu, namun produk-produk tersebut menjadi rancu saat dipertanyakan identitasnya. Selain itu pula, produk-produk tersebut mayoritas diproduksi semata-mata untuk memenuhi permintaan konsumen. Akibatnya, kriya justru mengalami kemunduran hanya sebagai seni kerajinan saja bahkan cenderung digolongkan sebagai benda kitsch 
(Kasiyan dalam Krisnanto, 2009: 413) yaitu akibat dari "keseluruhan orientasi kesadaran proses kreatif simbolisasinya lebih dijangkarkan pada aras fungsi praksis, bahkan komodikatif". Tidak sedikit masyarakat Indonesia lebih mengenal kriya sebagai produk kerajinan tangan ala perajin dibanding sebagai artefak kebudayaan yang membawa identitas budaya itu sendiri. Hal ini tidak mengherankan jika kita melihat adanya fenomena bahwa arus kebudayaan barat yang membanjiri masyarakat kita dengan istilah modern.

\section{Reposisi Kriyawan Keramik}

Istilah keramik umum dikenal oleh masyarakat Indonesia sebagai produk-produk industrial yang dibuat massal atau kerajinan gerabah tradisional hasil buatan tangan perajin. Stigma tersebut terbentuk akibat minimnya informasi dan edukasi yang disampaikan ke masyarakat mengenai ragam produk keramik yang sebenarnya sangat luas. Dalam konteks kriya, material keramik tidak hanya terbatas pada benda fungsi namun dapat pula diaplikasikan ke dalam bentukbentuk artistik estetis. Akan tetapi unsur fungsi merupakan unsur yang mutlak harus ada di dalam kekaryaan ataupun produk kriya keramik. Hal ini merupakan hal dasar yang membedakan kriya keramik dan seni keramik.

Tidak dapat dipungkiri bahwa kriya keramik sudah mengambil posisi baru. Dahulu kesenjangan antara sentra dan industri besar sangat dalam dan mengakibatkan adanya kontras yang terlalu mencolok antara produk masinal yang mampu memproduksi keramik dengan kualitas tinggi dengan keramik produksi rumahan yang dibuat oleh perajin. Kini kesenjangan tersebut sudah bisa dikatakan mulai dipersempit dengan adanya peran dari praktisi dan akademisi yang fokus untung mengembangkan kriya keramik khususnya melalui inovasi desain, material, dan pengelolaan bisnis.

Pada sektor perajin di sentra-sentra sudah sejak dahulu mendapatkan bimbingan dan pembinaan. Beberapa contohnya, antara lain sosok: Sapto Hudoyo yang sudah sejak era tahun 1970-an membina para perajin gerabah di desa Kasongan; Chitaru Kawasaki, seorang profesor dari Jepang yang membina perajin gerabah daerah Bayat, Klaten; dan Asmudjo J. Irianto yang kerap terlibat di berbagai pembinaan di sentra-sentra gerabah di luar Jawa. Semua figur tersebut merupakan pakar di bidang keramik yang membawa pengaruh besar bagi perkembangan kriya keramik di ranah perajin. Imbasnya tentu saja memberikan keuntungan tidak hanya dari segi material tetapi juga berupa investasi identitas yang akan menjadi ciri khas akan produkproduk dari daerah tersebut di masa mendatang.

Munculnya istilah designer-maker adalah desainer sekaligus perajin yang secara langsung terlibat dalam proses produksi. Hal ini merupakan fenomena terbaru yang sedang marak kembali semenjak tahun 2005. Pada saat itu para desainer ataupun kriyawan keramik berani membuka studio mandiri sekaligus memiliki label dagang mereka sendiri. Oleh karena itu, pola studio seperti ini berbeda dengan studio atau workshop di tahun-tahun sebelumnya yang masih berorientasi pada proyek. Desainer dalam kategori ini mampu secara kompetensi atau keahlian membuat dan merancang benda-benda keramik baik sebagai benda hias maupun fungsional secara terstruktur dan sistematis. $\mathrm{Di}$ samping pengetahuan produksi dan material yang harus dimiliki, mereka mampu secara keilmuan desain untuk mengembangkan produknya tidak hanya berdasarkan permintaan pasar namun juga identitas yang konsisten, mampu mempertahankan ciri khas mereka, sehingga 
pasar pun dengan mudah mengenali produk yang mereka buat.

Selanjutnya akan dipaparkan gambaran tentang apa yang dimaksud dengan sentra perajin, industri berbasis kriya, dan studio mandiri dengan mengambil contoh studi kasus dari beberapa usaha kriya keramik yang sudah berjalan.

\section{Sentra Gerabah Kasongan (Sentra Perajin)}

Gerabah secara material tergolong dalam material keramik yang umumnya menggunakan tanah liat dengan jenis earthenware, terakota, atau majolika. Gerabah juga merupakan salah satu peninggalan budaya yang sangat tua. Berbagai penelitian membuktikan bahwa kebudayaan membuat gerabah sudah dimulai sejak zaman neolitikum yang pada waktu itu merupakan awal mula manusia mengenal proses bercocok tanam dan tinggal menetap di suatu tempat. Pada masa itu, gerabah sudah diproduksi secara luas dan banyak digunakan masyarakat karena tahan air, sederhana, dan mudah dibuat, sehingga tradisi membuat gerabah selalu ada dan berkembang di berbagai tempat. Seiring dengan perkembangan kebutuhan hidup, pemahaman terhadap kearifan dan pengetahuan lokal, serta tingkat pemakaian teknologi dalam kebudayaan manusia, gerabah terus mengalami perubahan. Di Indonesia, perkembangan gerabah tidak lepas dari jasa para perajin di daerah-daerah yang hingga saat ini masih terus terjaga.

Kasongan merupakan salah satu sentra gerabah yang masih bertahan hingga saat ini. Sentra ini berlokasi di Kabupaten Bantul, Provinsi Daerah Istimewa Yogyakarta. Ragam produknya sangat bervariasi dari benda-benda fungsional, seperti peralatan makan dan peralatan dapur tradisional hingga bendabenda hias, seperti gentong, guci, dan patung hias. Tradisi membuat gerabah ini telah berlangsung sejak lama sebagai usaha mempertahankan hidup akibat lahan pertanian di Kasongan dianggap kurang produktif dan sebagai usaha masyarakat yang memerlukan berbagai wadah untuk peralatan rumah tangga.

Sistem produksi di Kasongan sudah masih cenderung tradisional menggunakan jerami dan tungku bak yang berbahan bakar kayu dan fokus pada keramik bakaran rendah atau yang umum disebut gerabah. Perajin yang kini bekerja di Kasongan umumnya ialah penduduk asli dan pendatang dari Brebes, Jawa Tengah. Teknik yang digunakan pun masih tradisional dengan teknik pembentukan manual dan belum banyak memanfaatkan peralatan produksi yang modern. Dekorasi akhir yang diaplikasikan sudah jarang yang menggunakan teknik tempel khas Kasongan kecuali untuk pesanan tertentu dan telah digantikan dengan dekorasi menggunakan berbagai macam jenis cat.

Era tahun 1960-an hingga 1990-an merupakan masa-masa yang sangat penting bagi Kasongan karena pada masa itu Kasongan mengalami berbagai macam masukan-masukan baru yang sangat berpengaruh pada produkproduk gerabahnya hingga kini. Salah satu seniman yang pernah terlibat di Kasongan pada masa itu ialah Sapto Hudoyo yang kemudian bersama dengan para perajin mengembangkan teknik tempel yang menjadi ciri khas produk gerabah hias di Kasongan hingga saat ini.

Berdasarkan penelitian Dwi Budiwiwaramulya pada tahun 1998, desain gerabah Kasongan memang dianggap berkembang cukup pesat karena telah mengenal penggunaan material-material dan teknik-teknik baru. Akan tetapi ciri khas Kasongan disimpulkan mulai memudar karena produksi yang berlangsung setelah tahun 1990 cenderung lebih berorientasi pada permintaan pasar, sehingga beberapa produk khas 
Kasongan yang kurang dilirik pasar cenderung ditinggalkan.

\section{2. "Kandura Keramik" (Studio Mandiri)}

Berdiri pada tanggal 17 Agustus 2005 sebagai sebuah studio mandiri yang fokus pada produksi benda keramik fungsional khususnya peralatan makan dan minum serta berbagai aksesoris fashion, seperti kalung dan cincin. Produk-produk mereka selalu tematik dan bermain dengan warna-warna yang cenderung cerah serta didukung pengaplikasian glasir yang baik. Ketidakrapian justru dijadikan nilai jual untuk produk-produk mereka karena "Kandura" masih mengedepankan potensi handmade yang membuat setiap produk yang mereka buat memiliki karakter personal.

Kapasitas produksi mereka masih dalam skala menengah namun dapat dikategorikan berkembang pesat karena hanya dalam 5 tahun sejak didirikan mereka sudah mampu meningkatkan kapasitas produksi mereka cukup tinggi. Studio yang tidak terlalu besar memudahkan pengelolaan studio, di samping adanya pembagian tugas di antara keempat pemilik sekaligus desainer dari "Kandura". Peralatan yang dimiliki pun sudah tergolong modern dan tergolong lengkap untuk kategori studio mandiri.

Posisi mereka sebagai desainer memegang peranan penuh terhadap rancangan produk-produk yang mereka hasilkan. Ditambah dengan pengetahuan material yang dikuasai dengan baik, mereka mampu mengembangkan eksperimeneksperimen baru untuk mendapatkan kualitas material keramik dengan karakter-karakter khusus. Di dalam proses produksi pun terkadang mereka terlibat langsung, tidak hanya sebatas pengawasan terhadap kualitas produk namun juga keterlibatan dalam pengerjaan produknya. Hal ini lah yang menjadi kelebihan mereka sebagai designer-maker yang membedakannya antara perajin dan industri.

\section{3. "Jenggala Keramik Bali" (Industri)}

"Jenggala" berdiri tahun 1976 oleh keramikus asal Selandia Baru bernama Brent Hesselyn dan seorang pengusaha perhotelan di Bali bernama Wija Waworuntu dan anaknya, Ade Waworuntu. Dibangun pertama kali di daerah Batu Jimbar, Sanur sebelum kemudian pindah ke daerah Jimbaran pada tahun 2000. "Jenggala" merupakan salah satu industri yang bergerak di bidang kriya keramik yang dianggap berhasil menggabungkan potensi teknologi, desain, dan keterampilan tangan.

Desain-desain "Jenggala" berangkat dari inspirasi mengenai potensi budaya Bali. Salah satunya ialah patung Cili yang merupakan Dewi Sri atau dewi kesuburan bagi masyarakat Bali yang kemudian menjadi logo perusahaan. Hingga saat ini Jenggala terus mengembangkan desain dan eksperimen glasirnya yang masih mengangkat tema-tema tradisi lokal Indonesia. Salah satu puncak kesuksesan mereka adalah saat desainer kendi mereka yang didesain oleh Jessika Tirtanirmala berhasil meraih penghargaan dari UNESCO. Kolaborasi dengan berbagai seniman dan desainer baik lokal maupun mancanegara juga sering dilakukan. Selain sebagai daya tarik dan daya jual produkproduk mereka, dengan berkolaborasi diharapkan mampu mendapatkan keragaman dalam mengeksplor kemungkinan bentuk ataupun dekorasi baru dalam produknya atau bahkan menciptakan karya seni keramik yang berupa gabungan antara keahlian sang seniman dengan kemampuan produksi menggunakan alat-alat industrial.

Keunggulan dari industri besar seperti "Jenggala" adalah mereka mampu mendirikan departemen khusus untuk penelitian dan pengembangan yang didukung tenaga ahli di 
bidang material keramik. Departemen ini bertugas untuk mengontrol setiap bahan yang digunakan untuk produksi agar kualitas material tetap stabil. Penelitian untuk menemukan glasir-glasir ataupun campuran tanah baru pun dilakukan guna menunjang kebutuhan desain-desain baru. Suplai bahan berkualitas pun mampu mereka datangkan tidak hanya dari Bali ataupun luar Bali saja. Beberapa bahan yang digunakan mampu didatangkan dari luar negeri untuk memenuhi kualitas material yang ingin dikembangkan.

Dari segi alat-alat produksi pun "Jenggala Keramik" memiliki peralatan yang modern dalam menunjang kebutuhan produksi yang cepat serta berkuantitas banyak. Akan tetapi "Jenggala Keramik" tetap melibatkan unsur kerajinan tangan pada produkproduknya khususnya dalam proses dekorasi yang membutuhkan detail yang cukup sulit jika dicapai dengan mesin-mesin industri. Hal ini justru memberikan keuntungan tersendiri, yakni produk-produk "Jenggala" menjadi terkenal dengan ciri khas handmade dan secara sosial mereka mampu membuka lapangan pekerjaan yang lebih luas dengan memberdayakan para perajin keramik untuk terlibat bersama mereka sehingga keahlian keramik yang dimiliki masih tetap terjaga.

\section{Studi Komparasi}

Melihat gambaran ketika jenis usaha di atas, dapat dipetakan bagaimana setiap sektor memiliki ciri, potensi, dan kekurangan masingmasing. Latar belakang masing-masing sektor sangat memengaruhi bagaimana usaha tersebut tumbuh sesuai perkembangan, baik perkembangan pasar maupun perkembangan teknologi yang dimiliki.

Setiap sektor memiliki target pasarnya masing-masing. Kasongan fokus pada pasar yang sudah terbentuk dan rutin melakukan transaksi perdagangan dengan Kasongan. "Kandura Keramik" sebagai sebuah studio yang independen memiliki fleksibilitas dalam bekerja dan membuka pasar mereka sendiri melalui proyek, di samping produk retail yang secara konstan diproduksi. Sedangkan "Jenggala Keramik" sebagai sebuah usaha yang sudah mapan dengan pasar yang cukup stabil sudah lebih menfokuskan diri pada pengembangan desain yang lebih liberal dan tidak terlalu terikat pada kemauan pasar, sehingga pengembangan di bidang riset, baik desain maupun bahan baku keramiknya mampu berjalan lebih baik.

Pola usaha sentra perajin di Kasongan masih bersifat hierarkis, dengan kondisi perajin dibagi menjadi perajin skala kecil atau rumahan, skala sedang, dan skala besar. Skala ini ditentukan dari kapasitas produksi dan cakupan pasar yang dimiliki setiap tingkatan. Perajin skala besar dipastikan memiliki cakupan pasar yang luas dan pada umumnya sudah mampu melakukan kegiatan ekspor dan berpameran di berbagai pameran perdagangan internasional. Guna mendukung produksinya yang tergolong berkuantitas banyak, perajin skala besar akan meminta dukungan produksi dari perajin skala kecil dan menengah. Pada akhirnya, setiap tingkatan memiliki hubungan saling mendukung. Perajin skala kecil akan mendukung produksi perajin skala menengah, dan perajin skala menengah akan mendukung produksi perajin skala besar.

Sistem usaha seperti yang diterapkan di Kasongan memiliki keuntungan dalam hal pemerataan pengembangan usaha karena pola mutualisme yang terjadi di dalam hierarki perajin. Namun sistem ini juga memiliki risiko karena fokus usaha masih didominasi oleh perajin skala besar yang berinteraksi langsung dengan konsumen utama, khususnya pada aspek pengembangan desain dan keberlangsungan produk-produk tradisi. 
Dengan berlakunya sistem ini, desain yang berkembang akan sangat didominasi oleh perajin skala besar yang mengacu pada permintaan dominan yang berlaku. Hal ini menyebabkan perajin skala kecil dan menengah mau tidak mau mengikuti pasar yang dominan tersebut. Dengan pola usaha seperti ini dapat diprediksi bahwa desaindesain gerabah tradisional di Kasongan agak mengalami stagnansi perkembangan karena umumnya produk gerabah tradisional dibuat oleh perajin di skala tersebut.

Pola usaha studio mandiri seperti "Kandura" memiliki masalah yang berbeda dengan Kasongan. Tumbuh dengan latar belakang akademis dan usia usaha yang masih cukup muda membuat mereka lebih berani dalam melakukan eksplorasi dan membuka pasar mereka sendiri. Ketidakterikatan mereka akan tradisi juga menjadikan desain-desain yang dihasilkan memiliki batasan yang luas. Desain mereka lahir dari eksplorasi dan proses kreatif terhadap tema-tema tertentu. Secara teknis, studio seperti ini sudah mampu mengaplikasikan teknik-teknik pembentukan yang lebih modern, seperti teknik cetak menggunakan gips, teknik putar menggunakan meja putar, dan pembakaran dengan tungku modern yang sudah menggunakan gas.

Adanya studio mandiri seperti ini tentu saja menghadirkan pola baru dalam sistem kerja dan hadirnya desain-desain baru di ranah kriya keramik. Produk yang dibuat dirancang melalui proses desain yang lebih terstruktur dibanding perajin di sentra-sentra daerah, seperti Kasongan. Akan tetapi kecenderungan produk dari studio mandiri seperti ini justru lebih mengarah kepada desain-desain yang kontemporer dan cenderung tidak mengangkat tema-tema tradisi lokal. Hal ini, berdasarkan pengamatan, kembali mengacu pada konsumen yang menjadi target produk mereka, yakni konsumen menengah ke atas, di kota- kota besar dengan jangkauan umur dari 20-50 tahun.

Berbeda dengan "Jenggala Keramik" yang dari segi modal sudah sangat kuat didukung tenaga kerja dan kemampuan teknis yang lebih mahir, sehingga kemampuan produksinya pun jauh melampaui dua sektor lainnya. Akan tetapi "Jenggala" masih mampu melihat potensi dari sumber daya manusia khususnya di Bali yang memang memiliki bekal sebagai perajin keramik dan patung. Aset inilah yang kemudian dikelola oleh "Jenggala", sehingga komposisi dari aset-aset tersebut mampu menciptakan potensi yang maksimal. Contohnya adalah desain-desain mereka yang sudah mampu diproduksi dengan suhu bakar tinggi, sehingga eskplorasi material untuk mencapai kebutuhan desain yang rumit tidak lagi menjadi kendala.

"Jenggala" sudah mampu membentuk pasarnya sendiri dengan pengelolaan yang baik atas instrumen produksi yang mereka miliki. Desain sudah mampu mereka kedepankan sebagai nilai jual atas produk-produk mereka dan "Jenggala" juga tidak ragu dalam mengambil inspirasi produknya dari tradisitradisi lokal Indonesia. Kendala sudah tidak lagi berada di ranah desain, akan tetapi lebih kepada teknis manajerialnya.

\section{Penutup}

Pemaparan dan komparasi di atas memberikan gambaran umum kondisi kriya keramik di Indonesia saat ini yang terbagi menjadi tiga sector, yaitu sektor sentra, sektor studio mandiri, dan sektor Industri. Dari studi yang dilakukan diketahui bahwa eksplorasi bentuk-bentuk tradisi ataupun revitalisasi artefak tradisi masih mengalami hambatan. Hal ini disebabkan bahwa produk komersial kriya keramik saat ini masih dikuasai oleh pasar, diakibatkan dari kondisi perekonomian dari 
produsen yang masih bergantung pada pasar, sedangkan kemampuan untuk membentuk pasar tersendiri membutuhkan modal, baik finansial maupun intelektual yang memadai didukung dengan keberanian dalam mengambil langkah-langkah manajerial dan pemasaran.

Dengan didapatkannya gambaran tersebut diharapkan dapat membuka wawasan baru tentang potensi-potensi yang dapat dicapai dari sebuah karya ataupun produk kriya keramik. Peran akademisi dan praktisi sangat dibutuhkan di ketiga sektor tersebut. Perajin masih membutuhkan dorongan yang sangat besar untuk memajukan usahanya dan mencari identitasnya agar apa yang mereka hasilkan mampu diingat sebagai ciri khas di mata konsumen. Industri pun perlu disadarkan bahwa sumber daya manusia di Indonesia yang sangat berlimpah merupakan potensi yang sangat besar dalam industri kriya keramik. Banyak proses dalam produksi yang hanya mampu dicapai dengan pengerjaan tangan manusia dan hal ini justru yang dicari oleh konsumen saat ini. Hal ini menjadi bukti bahwa interaksi antara benda dan manusia dengan produk terus berlangsung dari awal benda tersebut dibuat hingga akhirnya digunakan. Peran studio mandiri pun tidak kalah besarnya walaupun masih dalam skala kecil. Desain yang mereka hasilkan mayoritas ialah hasil pemikiran yang out of the box dan tidak terbatas pada tekanan pasar. Karya atau produk kriya keramik yang mereka buat sering kali berupa hasil dari hal-hal kecil yang justru mampu menjadi nilai jual. Keberanian mendobrak pasar ini lah yang menyadarkan bahwa kriya keramik masih memiliki banyak hal yang bisa dieksplor.

\section{Daftar Pustaka}

Gustami, SP. 1992. Filosofi Seni Kriya Tradisional Indonesia, dalam SENI: Jurnal Pengetahuan dan Penciptaan
Seni. II/01 - Januari 1992. Yogyakarta: BP ISI.

Joedawinata, A. 2008. Unsur-Unsur Pemandu dalam Artefak Tradisional: Artefak Peralatan Anyaman di Kawasan Cirebon. Jurnal IImu Desain. Vol.3[2]. 57-74.

2005. "Unsur-unsur Pemandu dan Kontribusinya dalam Perwujudan Sosok Artefak Tradisional dengan Indikasi-indikasi Lokal yang Dikandung dan Dipancarkannya". PhD Theses. Bandung: Institut Teknologi Bandung.

Krisnanto, Sri, dkk. (eds.). 2009. Seni Kriya dan Kearifan Lokal dalam Lintas Ruang dan Waktu. Yogyakarta: BID ISI.

Lilley, D. 2009. Design For Sustainable Behaviour: Strategies and Perception. Design Studies 30 (2009), 704-720. doi:10.1016/j.destud.2009.05.001.

Mayall. W.H. 1979. Principles in Design. London: Design Council.

Nugraha, A. 2010. Transforming Tradition for Sustainability Through 'TCUSM' Tool. Synnyt Origins: Finnish Studies in Art. no.3, pp. $20-36$.

Piliang, Y.A. 2011. Dunia yang Dilipat. Bandung: Matahari.

Raharjo, T. 2009. Globalisasi Seni Kerajinan Keramik Kasongan. Yogyakarta: Program Pascasarjana ISI Yogyakarta.

Sumardjo, J. 2006. Estetika Paradoks. Bandung: Sunan Ambu Press.

Sutrisno, Mudji; Hendar Putranto (eds.). 2005. Teori-Teori Kebudayaan. Yogyakarta: Kanisius.

Tonkinwise, C. 2011. A Taste for Practice: Unrepressing Style in Design Thinking. Design Studies 32 (2011) 533-545. doi:10.1016/j.destud.2011.07.001.

Zainuddin, I.B. 2006. Desain, Sains Desain, dan Sains tentang Desain. Jurnal IImu Desain, Vol.1[1], h 17-33. Bandung: ITB. 